$\begin{array}{rr}\text { FIT(PPATOLOGI } & \text { Volume } 12 \text {, Nomor 1, Januari } 2016 \\ \text { IN D ONESIA } & \text { Halaman } 9-18 \\ \text { ISSN: } 0215-7950 & \text { DOI: } 10.14692 / \text { jfi. } 12.1 .9\end{array}$

\title{
Tanggap Genotipe Kacang Tanah Terhadap Penyakit Bercak Daun Cercospora dan Karat Daun Puccinia
}

\author{
Respons of Groundnut Genotypes to Cerospora \\ Leaf Spot and Puccinia Rust Diseases
}

\author{
Alfi Inayati* dan Eriyanto Yusnawan \\ Balai Penelitian Tanaman Aneka Kacang dan Umbi, Malang 65101
}

\begin{abstract}
ABSTRAK
Penyakit bercak daun dan karat merupakan penyakit penting pada kacang tanah yang mengganggu pertumbuhan dan mengurangi hasil kacang tanah. Penelitian ini bertujuan mengevaluasi ketahanan 13 genotipe kacang tanah terhadap penyakit bercak daun dan karat. Penelitian disusun dalam rancangan split plot dengan 3 ulangan. Petak utama adalah inokulasi propagul penyakit dan tanpa inokulasi, dan anak petak adalah genotipe kacang tanah. Pengamatan dilakukan terhadap jumlah pustul karat per daun, jumlah bercak per daun, intensitas penyakit karat, intensitas penyakit bercak daun untuk menentukan tingkat ketahanan genotipe, dan indeks luas daun. Peubah komponen hasil meliputi bobot brangkasan basah, jumlah polong isi per tanaman, jumlah polong hampa, dan bobot polong per tanaman. Penyakit bercak daun muncul lebih awal dibandingkan dengan karat. Semua genotipe kacang tanah yang diuji termasuk sangat rentan penyakit bercak daun dan hanya 1 genotipe termasuk rentan. Intensitas penyakit bercak daun dan karat berkorelasi negatif dengan hasil kacang tanah $(\mathrm{r}=-0.1-(-0.4))$. Penyakit bercak daun dan karat menyebabkan berkurangnya komponen hasil, antara lain bobot brangkasan basah (73.2 \%), jumlah polong isi (68\%), dan bobot polong (72.5\%). Jumlah polong hampa dan polong chipo meningkat masing-masing sampai 81 dan $56.4 \%$.
\end{abstract}

Kata kunci : inokulasi, intensitas penyakit, ketahanan genotipe, rentan

\begin{abstract}
Leaf spot and rust are two important diseases on groundnut. Both diseases are frequently found at the same time that influence the growth and reduce the yield of groundnut. This study was conducted to evaluate thirteen groundnut genotypes resistance to leaf spot and rust disease. The experiment was conducted using a split plot design and three replications, with inoculated and uninoculated treatment as main plot, and groundnut genotypes as the sub plot. Disease assessment was conducted by counting number of pustules per leaf, the number of spots per leaf, rust disease intensity, the intensity of leaf spot disease, and leaf area index. Yield components including stover weight, number of pods per plant, number of empty pods, number of chipo pods, and weight of pods per plant were recorded for both inoculated and uninoculated plants. The result showed that leaf spot disease developed earlier than rust disease. Only one genotype was susceptible to rust and the other 12 genotypes were very susceptible, whereas all genotypes tested were very susceptible to leaf spot. The intensity of rust and leaf spot diseases was negatively correlated with yield $(r=-0.1-(0.4))$. Rust and leaf spot diseases reduced the yield components including stover weight (73.2\%), number of pods $(68 \%)$, and weight of pods $(72.5 \%)$. The number of empty pods and chipo pods were increase to 81 and $56.4 \%$ respectively.
\end{abstract}

Key words: disease intensity, genotype resistance, inoculation, susceptible

*Alamat penulis korespondensi: Balai Penelitian Tanaman Aneka Kacang dan Umbi. Jalan Raya Kendalpayak KM 8, Kotak POS 66, Malang 65101.

Tel: 0341 801468, Faks: 0341801 496, Surel: alfiinayati2@gmail.com 


\section{PENDAHULUAN}

Penyakit bercak daun dan karat merupakan 2 penyakit penting pada kacang tanah. Gejala penyakit bercak daun dapat ditemui sejak awal pertumbuhan, yaitu 30 hari setelah tanam. Penyakit bercak awal disebabkan oleh Cercospora arachidicola dan pada umur lebih lanjut penyakit bercak juga dapat muncul yang disebabkan oleh $C$. personatum. Gejala bercak awal adalah munculnya bercak cokelat yang dikelilingi oleh halo berwarna kuning sedangkan penyakit bercak lanjut mempunyai bercak yang lebih gelap kehitaman dan tanpa halo.

Penyakit karat dapat terjadi bersamaan dengan penyakit bercak, namun seringkali gejala penyakit karat yang disebabkan oleh Puccinia arachidicola muncul setelah penyakit bercak daun. Penyakit karat ditandai dengan munculnya pustul (uredinium) berwarna oranye pada permukaan bawah daun yang kemudian berkembang menjadi nekrosis dan menyebabkan daun mengering.

Ketahanan kacang tanah terhadap penyakit bercak dan karat dipengaruhi oleh gen-gen tahan dan faktor lingkungan. Power et al. (2013) menyebutkan belum pernah dilaporkan adanya ketahanan yang lengkap pada kacang tanah, ketahanannya hanya bersifat sebagian dan yang berperan beberapa gen minor saja. Selain itu suhu dan kelembapan berpengaruh terhadap perkembangan penyakit dan patogenisitas.

Penilaian ketahanan terhadap penyakit bercak dan karat dilakukan dengan skor gejala penyakit secara visual. Pengamatan gejala dengan skoring keparahan penyakit merupakan cara penilaian yang terbaik karena heritabilitas ketahanan terhadap penyakit tinggi dan relatif mudah dilakukan (Pasupuleti et al. 2013). Genotipe yang tahan terhadap penyakit bercak daun mempunyai jumlah bercak sedikit dan sporulasi sedikit (Pensuk et al. 2003). Selain itu, genotipe yang tahan mempunyai masa inkubasi dan periode laten yang panjang, diameter bercak kecil, indeks sporulasi rendah, dan area kerusakan daun rendah (Ricker et al. 1985; Anderson et al.
1990; Dwivedi et al. 2002; Cantonwine et al. 2008). Secara morfologi, genotipe yang tahan mempunyai jaringan kutikula dan lapisan epidermis yang tebal, jumlah sel epidermis sedikit, ukuran dan jumlah stomata yang besar, serta lapisan lilin yang lebih tebal pada fase reproduktif (Sunkad dan Kulkarni 2006).

Penyakit bercak dan karat daun menyebabkan berkurangnya jumlah daun sehat, menyebabkan daun gugur sebelum waktunya, dan mengganggu proses fotosintesis sehingga berpengaruh pada berkurangnyajumlah polong dan proses pengisian polong (Cantonwine et al. 2006). Kehilangan hasil akibat kedua penyakit ini dapat mencapai 50-80\% (Hassan dan Beute 1977; Subrahmanyam et al. 1985). Varietas tahan dan toleran merupakan salah satu cara pengendalian penyakit pada kacang tanah. Penelitian ini bertujuan mengevaluasi ketahanan genotipe galur dan varietas kacang tanah.

\section{BAHAN DAN METODE}

Sebanyak 13 genotipe kacang tanah yang terdiri atas 7 galur harapan $(\mathrm{GH} 1, \mathrm{GH} 2, \mathrm{GH} 3$, GH4, GH8, GH11, dan J11) serta 6 varietas (Chico, Gajah, Kancil, Bison, Hypoma, dan Tuban) ditanam pada pot kantong plastik. Penelitian dilakukan mulai bulan Februari sampai Mei 2014 di rumah kasa Balitkabi pada kelembapan berkisar antara $80-85 \%$ dengan suhu $25-28{ }^{\circ} \mathrm{C}$. Penelitian disusun dalam rancangan split plot dengan 3 ulangan, yang tersarang dalam perlakuan. Faktor pertama ialah inokulasi penyakit dan tanpa inokulasi, faktor kedua adalah genotipe kacang tanah. Setiap genotipe kacang tanah ditanam dalam 3 pot dan setiap pot berisi 3 tanaman sehingga penelitian ini terdiri atas 78 unit percobaan. Pemupukan dan penyiangan yang diberikan sesuai rekomendasi $\left(50 \mathrm{~kg} \mathrm{ha}^{-1}\right.$ Urea, $100 \mathrm{~kg} \mathrm{ha}^{-1} \mathrm{SP} 36$, dan $50 \mathrm{~kg} \mathrm{ha}^{-1} \mathrm{KCl}$ ), penyiraman disesuaikan dengan kebutuhan dan diusahakan mencapai kelembapan tinggi, sehingga mendukung perkembangan penyakit. Satu set genotipe kacang tanah yang sama tanpa inokulasi buatan dan disemprot dengan fungisida berbahan aktif tiofanat 
metil dan difenokonazol digunakan sebagai pembanding.

Inokulasi menggunakan spora dari bercak dan karat daun kacang tanah dilakukan pada 4 minggu setelah tanam (MST). Spora untuk inokulum dikumpulkan dari daun kacang tanah varietas Kancil yang terserang bercak dan karat daun yang telah ditanam sebelumnya. Daun sumber inokulum diinkubasi selama 2 hari. Selanjutnya, spora karat dan bercak diluruhkan dalam wadah berisi air dan dihitung kerapatan konidiumnya hingga mencapai $10^{4} \mathrm{~mL}^{-1}$ dan disemprotkan pada daun tanaman uji.

Pengamatan dilakukan pada seluruh daun kacang tanah pada umur 4-9 MST dengan interval pengamatan 7 hari. Pengamatan meliputi jumlah pustul dan bercak pada setiap daun serta intensitas serangan penyakit karat dan bercak daun. Intensitas penyakit bercak dan karat daun dihitung menggunakan metode Subrahmanyam et al. (1995), demikian juga kriteria ketahanannya (Tabel 1). Genotipe kacang tanah dengan skor 1 termasuk dalam kategori tahan; skor 2-3 agak tahan; 4 agak rentan; 5-7 rentan; dan skor 8-9 sangat rentan.

Luas daun diukur untuk semua genotipe kacang tanah yang diinokulasi pada umur 5 minggu setelah inokulasi (MSI). Luas daun ini digunakan untuk menghitung jumlah bercak dan pustul per $100 \mathrm{~cm}^{2}$. Pengukuran luas daun diulangi untuk semua genotipe kacang tanah yang diinokulasi dan tanpa inokulasi pada umur 85 hari setelah tanam (HST) menggunakan Portable Leaf Area Meter CI-202, CID Inc. Persentase defoliasi

Tabel 1 Metode skoring untuk penilaian ketahanan genotipe kacang tanah terhadap penyakit bercak dan penyakit karat (Subrahmanyam et al. 1995)

\begin{tabular}{|c|c|c|c|}
\hline Penyakit bercak daun & Skor & $\begin{array}{c}\text { Intensitas penyakit } \\
(\%)\end{array}$ & Penyakit karat \\
\hline Tidak ada serangan & $1(\mathrm{~T})$ & 0 & Tidak ada serangan \\
\hline $\begin{array}{l}\text { Bercak nekrotik kecil pada } \\
\text { daun tertua }\end{array}$ & $2(\mathrm{AT})$ & $1-5$ & $\begin{array}{l}\text { Pustul kecil, jarang pada daun } \\
\text { tertua }\end{array}$ \\
\hline $\begin{array}{l}\text { Bercak kecil terutama } \\
\text { pada daun tertua, sporulasi } \\
\text { terpencar }\end{array}$ & 3 (AT) & $6-10$ & $\begin{array}{l}\text { Pustul jarang, pada daun tertua, } \\
\text { daun kering, sporulasi tidak } \\
\text { melimpah }\end{array}$ \\
\hline $\begin{array}{l}\text { Banyak bercak terutama } \\
\text { pada daun bawah daun dan } \\
\text { di tengah, gejala jelas }\end{array}$ & $4(\mathrm{AR})$ & $11-20$ & $\begin{array}{l}\text { Pustul besar atau kecil, sebagian } \\
\text { besar pada daun tertua dan daun } \\
\text { di tengah, gejala jelas }\end{array}$ \\
\hline $\begin{array}{l}\text { Bercak terlihat jelas pada } \\
\text { daun-daun bawah dan } \\
\text { tengah, sporulasi sedang, } \\
\text { daun menguning, defoliasi } \\
\text { beberapa daun tua }\end{array}$ & $5(\mathrm{R})$ & $21-30$ & $\begin{array}{l}\text { Banyak pustul terutama pada } \\
\text { daun terbawah dan tengah, daun } \\
\text { menguning terjadi nekrosis } \\
\text { pada beberapa daun bawah dan } \\
\text { tengah; sporulasi sedang }\end{array}$ \\
\hline $\begin{array}{l}\text { Seperti skor } 5 \text { dan bercak } \\
\text { bersporulasi melimpah }\end{array}$ & $6(\mathrm{R})$ & $31-40$ & $\begin{array}{l}\text { Seperti skor } 5 \text { pustul bersporulasi } \\
\text { melimpah }\end{array}$ \\
\hline $\begin{array}{l}\text { Gejala tampak jelas dari } \\
\text { jarak jauh, bercak pada } \\
\text { seluruh tanaman, defoliasi } \\
\text { daun bawah dan tengah }\end{array}$ & $7(\mathrm{R})$ & $41-60$ & $\begin{array}{l}\text { Pustul timbul pada seluruh } \\
\text { tanaman, daun bawah dan tengah } \\
\text { kering }\end{array}$ \\
\hline $\begin{array}{l}\text { Seperti skor } 7 \text { dengan } \\
\text { intensitas defoliasi berat }\end{array}$ & 8 (SR) & $61-80$ & $\begin{array}{l}\text { Seperti skor } 7 \text { dengan intensitas } \\
\text { daun mengering berat }\end{array}$ \\
\hline $\begin{array}{l}\text { Tanaman terserang berat, } \\
50-100 \% \text { daun mengering }\end{array}$ & 9 (SR) & $81-100$ & $\begin{array}{l}\text { Tanaman terserang berat, } \\
50-100 \% \text { daun mengering }\end{array}$ \\
\hline
\end{tabular}

T, tahan; AT, agak tahan; AR, agak rentan; R, rentan;, SR, sangat rentan 
akibat penyakit bercak daun dan karat dihitung per luasan daun.

Peubah komponen hasil yang diamati meliputi bobot brangkasan basah, jumlah polong isi per tanaman, jumlah polong hampa, dan bobot polong per tanaman. Tingkat toleransi suatu genotipe terhadap penyakit bercak dan karat dinilai dari persentase penurunan hasil dan indeks toleransi terhadap cekaman penyakit (disease stress tolerance index, DSTI). Persentase penurunan hasil dihitung menggunakan rumus:

$$
\frac{\left(\begin{array}{l}
\text { hasil biji pada set } \\
\text { tanpa inokulasi }
\end{array}\right)-\left(\begin{array}{l}
\text { hasil biji pada } \\
\text { set inokulasi }
\end{array}\right)}{\text { (hasil biji pada set tanpa inokulasi) }} \times 100 \%
$$

Indeks toleransi (disease stress tolerance index, DSTI) dihitung menggunakan rumus indeks toleransi terhadap cekaman (Fernandez 1992);

DSTI $=\frac{\left(\begin{array}{l}\text { hasil biji pada set } \\ \text { tanpa inokulasi }\end{array}\right) \times\left(\begin{array}{l}\text { hasil biji pada } \\ \text { set inokulasi }\end{array}\right)}{\text { (hasil biji pada set tanpa inokulasi) }}$

Data yang diperoleh dianalisis menggunakan sidik ragam dengan program SAS 9.1 pada taraf nyata $95 \%$. Jika hasil menunjukkan beda nyata, dilakukan uji lanjut dengan beda nyata terkecil pada taraf nyata $95 \%$.

\section{HASIL}

Gejala penyakit bercak daun muncul lebih awal dibandingkan dengan penyakit karat. Masa inkubasi penyakit bercak pada semua genotipe kacang tanah uji tidak berbeda nyata. Masa inkubasi terpendek 5.3 hari, yaitu pada genotipe GH3 dan varietas Chico dan tepanjang 6.1 hari pada genotipe J11, demikian juga periode laten terpendek 6.2 hari dan terlama 7 hari (Tabel 2). Pada 5 MST atau 1 MSI, bercak daun terlihat pada semua genotipe, dengan intensitas penyakit bervariasi antara 14.3$37.7 \%$. Jumlah bercak cenderung meningkat seiring dengan bertambahnya umur tanaman, demikian juga intensitas bercak daun. Pada $5 \mathrm{MSI}$, rerata jumlah bercak per $100 \mathrm{~cm}^{2}$ luas daun antara 42.9-137.9 bercak dengan gejala bercak daun telah mencapai daun muda yang sudah membuka sempurna. Intensitas bercak mencapai $91.8 \%$ sehingga semua genotipe kacang tanah tergolong sangat rentan penyakit bercak daun (Tabel 2).

Pustul sebagai penanda penyakit karat hanya muncul pada 5 genotipe saat 5 MST. Masa inkubasi penyakit karat lebih lama dibandingkan dengan penyakit bercak. Ratarata masa inkubasi penyakit karat 11.7 hari dengan masa inkubasi terpendek 10.7 hari dan terpanjang 12.7 hari, namun masa inkubasi semua genotipe uji tidak berbeda nyata. Periode laten penyakit karat pada penelitian ini berkisar 15.3-18.0 hari dengan rata-rata 16.1 hari (Tabel 3). Intensitas serangan karat pada 5 MST bervariasi 0-5\%. Selanjutnya perkembangan penyakit karat relatif lebih lambat dibandingkan dengan penyakit bercak yang terlihat pada jumlah pustul pada akhir pengamatan (9 MST), yaitu 1.0-4.5 pustul per daun dan rerata jumlah pustul per $100 \mathrm{~cm}^{2}$ luas daun antara 8.5-51.7 pustul. Namun demikian, gejala telah muncul sampai daun muda dibagian atas dengan rerata intensitas penyakit $84.4 \%$ (Tabel 3) sehingga semua genotipe tergolong rentan dan sangat rentan terhadap penyakit karat.

Luas daun yang masih berwarna hijau (sehat) sampai dengan 85 HST pada tanaman yang terinfeksi penyakit bercak daun dan karat sangat rendah, yakni $7.4-167.5 \mathrm{~cm}^{2}$. Tanaman sehat tanpa inokulasi rata-rata luasnya 260.2-995.5 $\mathrm{cm}^{2}$. Persentase defoliasi semua genotipe tergolong tinggi, yaitu 54-99\%. Besarnya persentase defoliasi juga tergambar pada rendahnya bobot brangkasan basah pada tanaman yang terinfeksi bercak daun dan korelasi negatif antara persentase defoliasi dan penurunan bobot brangkasan. Bobot brangkasan basah pada tanaman yang terinfeksi 41.4-64.4 g per tanaman, sedangkan pada tanaman yang sehat sangat tinggi, (150.4-272.4 g per tanaman) dengan rata-rata penurunan bobot brangkasan basah sebesar $73.2 \%$ (Tabel 4).

Infeksi penyakit bercak dan karat memengaruhi hasil dan komponen hasil kacang tanah. Hal ini juga tampak dari adanya korelasi negatif antara hasil dan intensitas 
Tabel 2 Masa inkubasi, periode laten, dan rerata jumlah bercak serta intensitas penyakit bercak daun Cercosporapada genotipe kacang tanah

\begin{tabular}{|c|c|c|c|c|c|c|c|c|c|c|}
\hline \multirow[t]{2}{*}{ Genotipe } & \multirow[t]{2}{*}{$\begin{array}{l}\text { Masa } \\
\text { inkubasi* } \\
\text { (hari) }\end{array}$} & \multirow[t]{2}{*}{$\begin{array}{l}\text { Periode } \\
\text { laten* } \\
\text { (hari) }\end{array}$} & \multicolumn{3}{|c|}{$\begin{array}{l}\text { Jumlah bercak } \\
\text { per daun } \\
\text { pada ...MST }\end{array}$} & \multirow[t]{2}{*}{$\begin{array}{l}\text { Jumlah bercak } \\
\text { (per } 100 \mathrm{~cm}^{2} \text { ) }\end{array}$} & \multicolumn{3}{|c|}{$\begin{array}{c}\text { Intensitas penyakit } \\
\text { pada... MST } \\
(\%)\end{array}$} & \multirow[t]{2}{*}{$\begin{array}{c}\text { Kriteria } \\
\text { ketahanan }\end{array}$} \\
\hline & & & 5 & 7 & 9 & & 5 & 7 & 9 & \\
\hline GH1 & $5.56 \mathrm{a}$ & $6.22 \mathrm{a}$ & 0.3 & 1.1 & 9.3 & 83.2 & 19 & 70 & 90 & SR \\
\hline $\mathrm{GH} 2$ & $5.67 \mathrm{a}$ & $7.00 \mathrm{a}$ & 0.5 & 2.3 & 14.8 & 110.1 & 25 & 74 & 93 & SR \\
\hline GH3 & $5.33 \mathrm{a}$ & $7.00 \mathrm{a}$ & 0.5 & 3.2 & 12.0 & 137.9 & 30 & 72 & 92 & SR \\
\hline GH4 & $5.78 \mathrm{a}$ & $6.89 \mathrm{a}$ & 0.3 & 3.1 & 9.3 & 89.5 & 14 & 63 & 92 & SR \\
\hline GH8 & $6.00 \mathrm{a}$ & $7.00 \mathrm{a}$ & 0.3 & 3.0 & 14.8 & 107.8 & 14 & 69 & 90 & SR \\
\hline GH11 & $6.00 \mathrm{a}$ & $7.00 \mathrm{a}$ & 0.8 & 2.4 & 17.0 & 132.7 & 34 & 74 & 100 & SR \\
\hline J11 & $6.11 \mathrm{a}$ & $7.00 \mathrm{a}$ & 0.3 & 2.4 & 13.6 & 111.9 & 15 & 71 & 90 & SR \\
\hline Chico & $5.33 \mathrm{a}$ & $7.00 \mathrm{a}$ & 0.8 & 3.0 & 10.0 & 79.7 & 33 & 76 & 80 & SR \\
\hline Gajah & $5.56 \mathrm{a}$ & $7.00 \mathrm{a}$ & 1.1 & 2.6 & 7.3 & 59.1 & 36 & 76 & 90 & SR \\
\hline Kancil & $5.67 \mathrm{a}$ & $7.00 \mathrm{a}$ & 1.0 & 3.3 & 10.4 & 66.7 & 33 & 72 & 85 & SR \\
\hline Bison & $5.56 \mathrm{a}$ & $7.00 \mathrm{a}$ & 0.4 & 5.3 & 9.0 & 76.1 & 17 & 76 & 100 & SR \\
\hline Hypoma & $5.44 \mathrm{a}$ & $7.00 \mathrm{a}$ & 0.5 & 3.8 & 7.6 & 53.6 & 21 & 72 & 100 & SR \\
\hline Tuban & $5.67 \mathrm{a}$ & $7.00 \mathrm{a}$ & 0.6 & 3.8 & 6.3 & 42.9 & 34 & 71 & 92 & SR \\
\hline Rerata & 5.67 & 6.93 & 0.6 & 3.0 & 10.9 & 88.6 & 25.1 & 72.1 & 91.8 & \\
\hline $\mathrm{Sd}^{1}$ & 0.25 & 0.22 & 0.3 & 1.0 & 3.3 & 29.8 & 8.5 & 3.5 & 5.7 & \\
\hline
\end{tabular}

*Angka yang diikuti dengan huruf yang sama menunjukkan tidak beda nyata

${ }^{1} \mathrm{Sd}$, Standar deviasi

SR, sangat rentan

Tabel 3 Masa inkubasi, periode laten dan rerata jumlah bercak serta intensitas penyakit karat Puccinia pada genotipe kacang tanah

\begin{tabular}{|c|c|c|c|c|c|c|c|c|c|c|}
\hline \multirow[t]{2}{*}{ Genotipe } & \multirow[t]{2}{*}{$\begin{array}{c}\text { Masa } \\
\text { inkubasi* } \\
\text { (hari) }\end{array}$} & \multirow[t]{2}{*}{$\begin{array}{l}\text { Periode } \\
\text { laten* } \\
\text { (hari) }\end{array}$} & \multicolumn{3}{|c|}{$\begin{array}{c}\text { Jumlah pustul per } \\
\text { daun pada ...mst }\end{array}$} & \multirow[t]{2}{*}{$\begin{array}{l}\text { Jumlah bercak } \\
\left(100 \mathrm{~cm}^{2}\right)^{-1}\end{array}$} & \multicolumn{3}{|c|}{$\begin{array}{c}\text { Intensitas penyakit } \\
\text { pada ... MST } \\
(\%) \\
\end{array}$} & \multirow[t]{2}{*}{$\begin{array}{c}\text { Kriteria } \\
\text { ketahanan }\end{array}$} \\
\hline & & & 5 & 7 & 9 & & 5 & 7 & 9 & \\
\hline GH1 & $12.0 \mathrm{a}$ & $16.7 \mathrm{a}$ & 0.0 & 4.5 & 5.0 & 45.0 & 0 & 40 & 57 & $\mathrm{R}$ \\
\hline GH2 & $13.3 \mathrm{a}$ & $16.7 \mathrm{a}$ & 0.0 & 4.0 & 3.0 & 22.4 & 0 & 34 & 92 & SR \\
\hline GH3 & $10.7 \mathrm{a}$ & $15.3 \mathrm{a}$ & 11.2 & 9.0 & 4.5 & 51.7 & 5 & 31 & 100 & SR \\
\hline GH4 & $10.7 \mathrm{a}$ & $15.3 \mathrm{a}$ & 6.4 & 7.5 & 2.5 & 24.2 & 5 & 40 & 80 & SR \\
\hline GH8 & $12.7 \mathrm{a}$ & $18.0 \mathrm{a}$ & 0.0 & 2.0 & 2.0 & 14.6 & 0 & 33 & 90 & SR \\
\hline GH11 & $12.0 \mathrm{a}$ & $15.3 \mathrm{a}$ & 0.0 & 2.5 & 5.0 & 39.0 & 0 & 34 & 80 & SR \\
\hline $\mathrm{J} 11$ & $11.1 \mathrm{a}$ & $15.1 \mathrm{a}$ & 0.0 & 1.0 & 2.0 & 16.4 & 0 & 30 & 100 & SR \\
\hline Chico & $11.3 \mathrm{a}$ & $16.0 \mathrm{a}$ & 0.0 & 2.0 & 1.5 & 12.0 & 0 & 32 & 70 & SR \\
\hline Gajah & $11.3 \mathrm{a}$ & $16.0 \mathrm{a}$ & 0.0 & 2.5 & 1.5 & 12.2 & 0 & 30 & 75 & SR \\
\hline Kancil & $11.3 \mathrm{a}$ & $15.3 \mathrm{a}$ & 0.0 & 2.5 & 3.5 & 22.5 & 0 & 31 & 90 & SR \\
\hline Bison & $11.6 \mathrm{a}$ & $16.9 \mathrm{a}$ & 1.4 & 2.0 & 1.0 & 8.5 & 3 & 25 & 90 & SR \\
\hline Hypoma & $12.2 \mathrm{a}$ & $16.9 \mathrm{a}$ & 0.2 & 2.0 & 2.0 & 14.1 & 1 & 30 & 83 & SR \\
\hline Tuban & $11.6 \mathrm{a}$ & $15.6 \mathrm{a}$ & 0.8 & 2.0 & 1.5 & 10.3 & 1 & 36 & 90 & SR \\
\hline Rerata & 11.7 & 16.1 & 1.5 & 3.3 & 2.7 & 22.5 & 1.2 & 32.7 & 84 & \\
\hline $\mathrm{Sd}^{1}$ & 0.8 & 0.9 & 3.4 & 2.3 & 1.4 & 14.0 & 1.9 & 4.1 & 12 & \\
\hline
\end{tabular}

*Angka yang diikuti dengan huruf yang sama menunjukkan tidak beda nyata

${ }^{1} \mathrm{Sd}$, Standar deviasi

$\mathrm{R}$, rentan; SR, sangat rentan. 
Tabel 4 Persentase defoliasi dan bobot brangkasan basah pada genotipe kacang tanah uji

\begin{tabular}{lccc}
\hline & Defoliasi* & \multicolumn{2}{c}{ Bobot brangkasan basah per tanaman* } \\
Genotipe & $(\%)$ & Inokulasi & Tanpa inokulasi \\
\cline { 3 - 4 } & $81.1 \mathrm{~g}$ & $60.0 \mathrm{e}$ & $148.6 \mathrm{~d}$ \\
GH1 & $84.2 \mathrm{ef}$ & $47.7 \mathrm{e}$ & $181.8 \mathrm{bcd}$ \\
GH2 & $99.0 \mathrm{a}$ & $48.2 \mathrm{e}$ & $182.7 \mathrm{bcd}$ \\
GH3 & $89.0 \mathrm{~cd}$ & $44.6 \mathrm{e}$ & $150.4 \mathrm{~d}$ \\
GH4 & $82.7 \mathrm{f}$ & $43.2 \mathrm{e}$ & $202.3 \mathrm{bcd}$ \\
GH8 & $54.0 \mathrm{i}$ & $41.4 \mathrm{e}$ & $162.7 \mathrm{~cd}$ \\
GH11 & $85.0 \mathrm{e}$ & $44.3 \mathrm{e}$ & $272.4 \mathrm{a}$ \\
J11 & $80.2 \mathrm{~g}$ & $42.5 \mathrm{e}$ & $175.1 \mathrm{bcd}$ \\
Chico & $80.4 \mathrm{~g}$ & $55.9 \mathrm{e}$ & $192.2 \mathrm{bcd}$ \\
Gajah & $87.8 \mathrm{~d}$ & $62.3 \mathrm{e}$ & $218.8 \mathrm{abc}$ \\
Kancil & $91.5 \mathrm{~b}$ & $51.0 \mathrm{e}$ & $204.6 \mathrm{bcd}$ \\
Bison & $89.6 \mathrm{c}$ & $64.3 \mathrm{e}$ & $215.7 \mathrm{abc}$ \\
Hypoma & $78.7 \mathrm{~h}$ & $60.5 \mathrm{e}$ & $227.6 \mathrm{ab}$ \\
Tuban & &
\end{tabular}

*Angka yang diikuti dengan huruf yang sama menunjukkan tidak beda nyata

serangan penyakit $(\mathrm{r}=-0.1-(-0.4)$ yang berarti intensitas penyakit yang tinggi akan menurunkan hasil. Rerata jumlah polong isi pada genotipe yang terinfeksi bervariasi antara 8.0 dan 20.6 polong per tanaman, sedangkan pada kondisi tidak terinfeksi dapat mencapai 29.8-61.8 polong per tanaman (Gambar 1). Secara keseluruhan penyakit bercak dan karat menyebabkan pengurangan jumlah polong sebesar $68 \%$, hal ini juga terlihat dari jumlah polong yang lebih rendah pada 8 genotipe dibandingkan dengan rata-rata pada kelompoknya dan hanya 5 genotipe saja yang jumlah polongnya lebih tinggi.

Rerata jumlah polong hampa dan calon polong kacang tanah (polong chipo) meningkat pada tanaman yang terinfeksi penyakit bercak daun dan karat (Gambar 2 dan 3). Jumlah polong hampa pada genotipe yang terinfeksi bervariasi antara 0.8 dan 4.1 polong per tanaman, sedangkan pada tanaman yang sehat paling tinggi hanya 1.5 polong per tanaman. Infeksi penyakit bercak dan karat meningkatkan jumlah polong hampa dan chipo masing-masing sebesar $81 \%$ dan $56.4 \%$.

Pengaruh infeksi bercak daun dan karat juga terlihat pada potensi hasil polong atau biji per tanaman dinilai dari bobot polong per tanaman. Bobot polong pada genotipe yang diinokulasi berkisar antara 15.1 dan 26.9 g per tanaman, sedangkan pada tanaman yang sehat antara 59.1 dan 103.1 g per tanaman (Gambar 4). Penurunan hasil akibat penyakit bercak Cercospora dan karat Puccinia bervariasi bergantung pada genotipe, yaitu $61-85 \%$ dan rata-rata penurunan bobot polong sebesar $72.5 \%$. Toleransi genotipe kacang tanah yang diuji dinilai dari indeks toleransi terhadap penyakit bervariasi dari sedang hingga tinggi dengan nilai DSTI 0.45-0.81. Terdapat korelasi negatif yang sangat nyata $(r=-0.99$, $\mathrm{P}<0.05)$ antara penurunan hasil akibat penyakit dengan toleransi tanaman (Gambar 5).

\section{PEMBAHASAN}

Tanggap genotipe kacang tanah terhadap penyakit bercak daun dan karat bervariasi dinilai dari gejala penyakit (jumlah bercak, jumlah pustul, dan intensitas penyakit). Semua genotipe kacang tanah yang diuji termasuk sangat rentan terhadap penyakit bercak daun, meskipun varietas Tuban mempunyai jumlah bercak paling sedikit (42.9 bercak per $100 \mathrm{~cm}^{2}$ luas daun), namun intensitas serangan bercak mencapai $91.7 \%$ sehingga dikategorikan rentan. Jumlah bercak dipengaruhi oleh lingkungan (Ricker et al. 1985) sehingga untuk penilaian ketahanan perlu dikonfirmasi dengan peubah lainnya seperti 


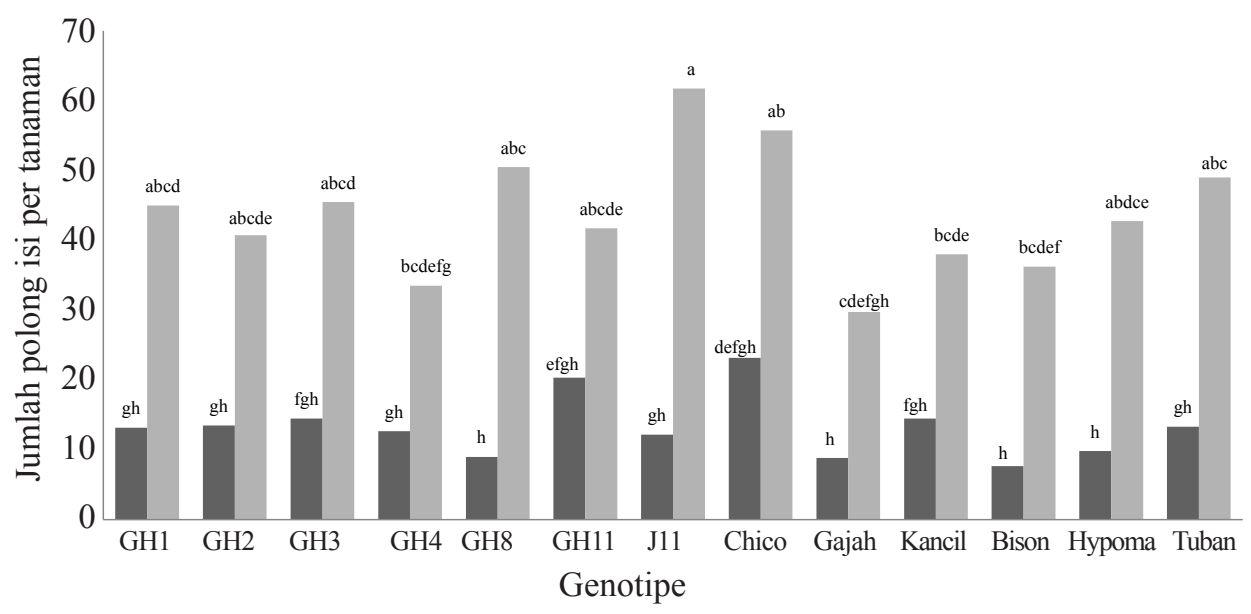

Gambar 1 Jumlah polong isi per tanaman pada genotipe kacang tanah yang diinokulasi dan tanpa inokulasi patogen bercak daun Cercospora dan karat Puccinia. $\mathbf{0}$, dengan diinokulasi; inokulasi. Huruf yang sama pada grafik menunjukkan tidak beda nyata BNT pada $\alpha 5 \%$.

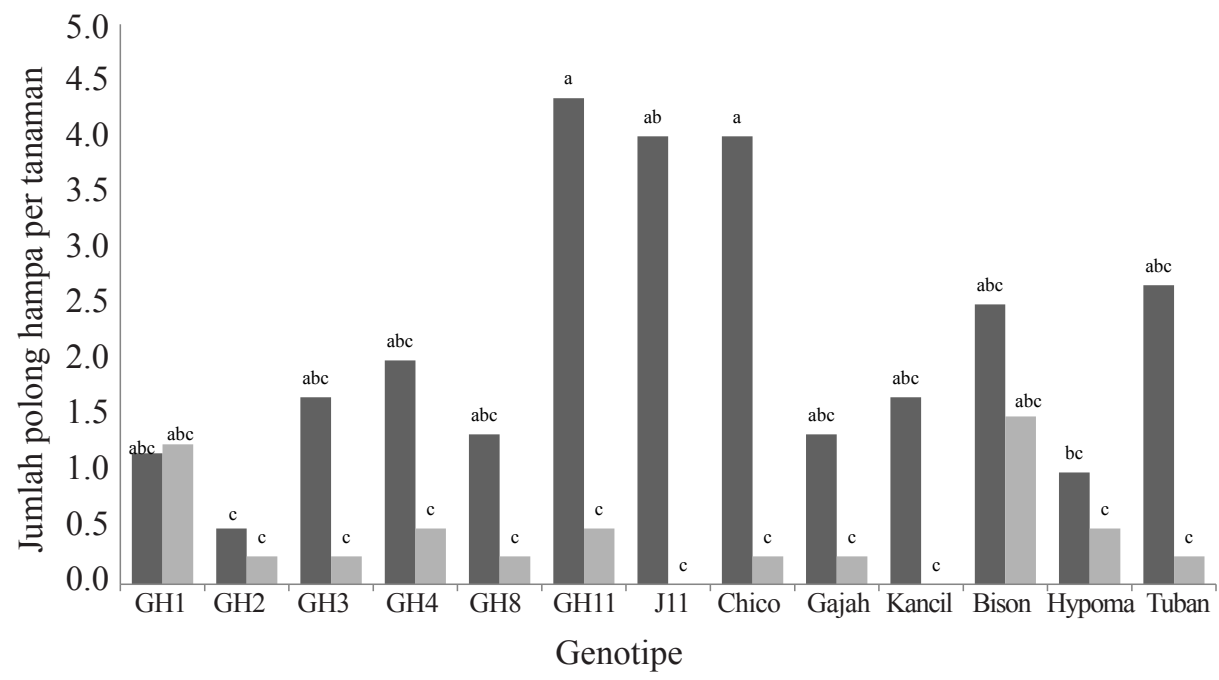

Gambar 2 Jumlah polong hampa per tanaman pada genotipe kacang tanah yang diinokulasi dan tanpa inokulasi patogen bercak daun Cercospora dan karat Puccinia. $\mathbf{0}$, dengan diinokulasi; inokulasi. Huruf yang sama pada grafik menunjukkan tidak beda nyata BNT pada $\alpha 5 \%$.

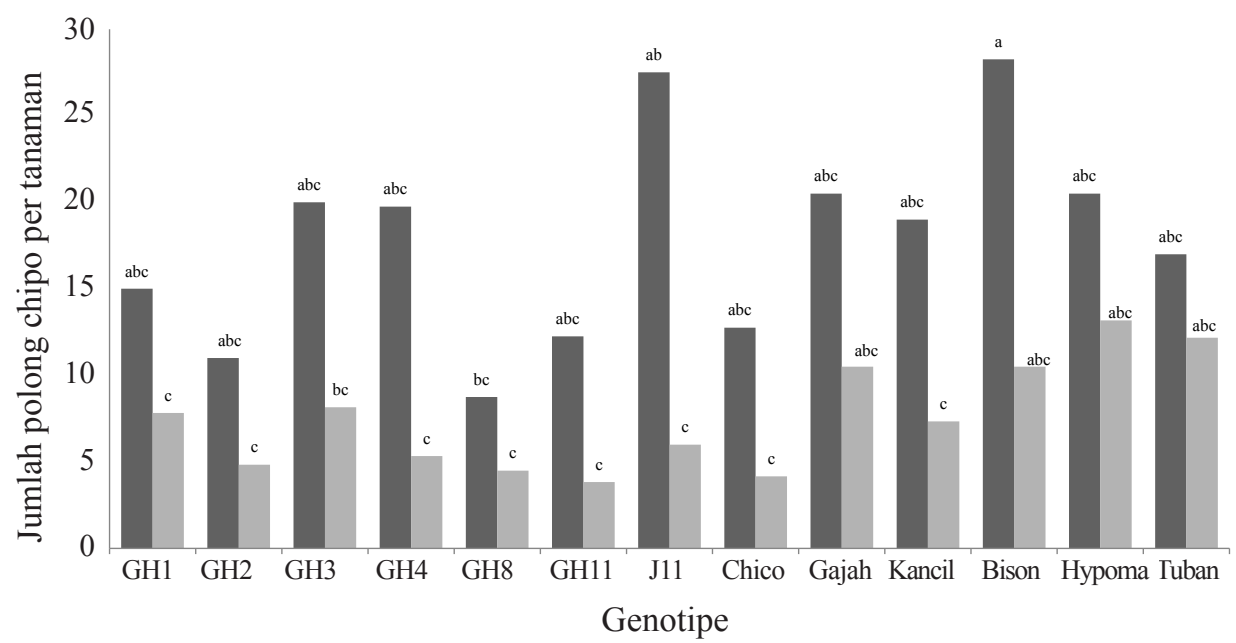

Gambar 3 Jumlah polong chipo per tanaman pada genotipe kacang tanah yang diinokulasi dan tanpa inokulasi patogen bercak Cercospora daun dan karat Puccinia. $\mathbf{0}$, dengan diinokulasi; inokulasi. Huruf yang sama pada grafik menunjukkan tidak beda nyata BNT pada $\alpha 5 \%$. 


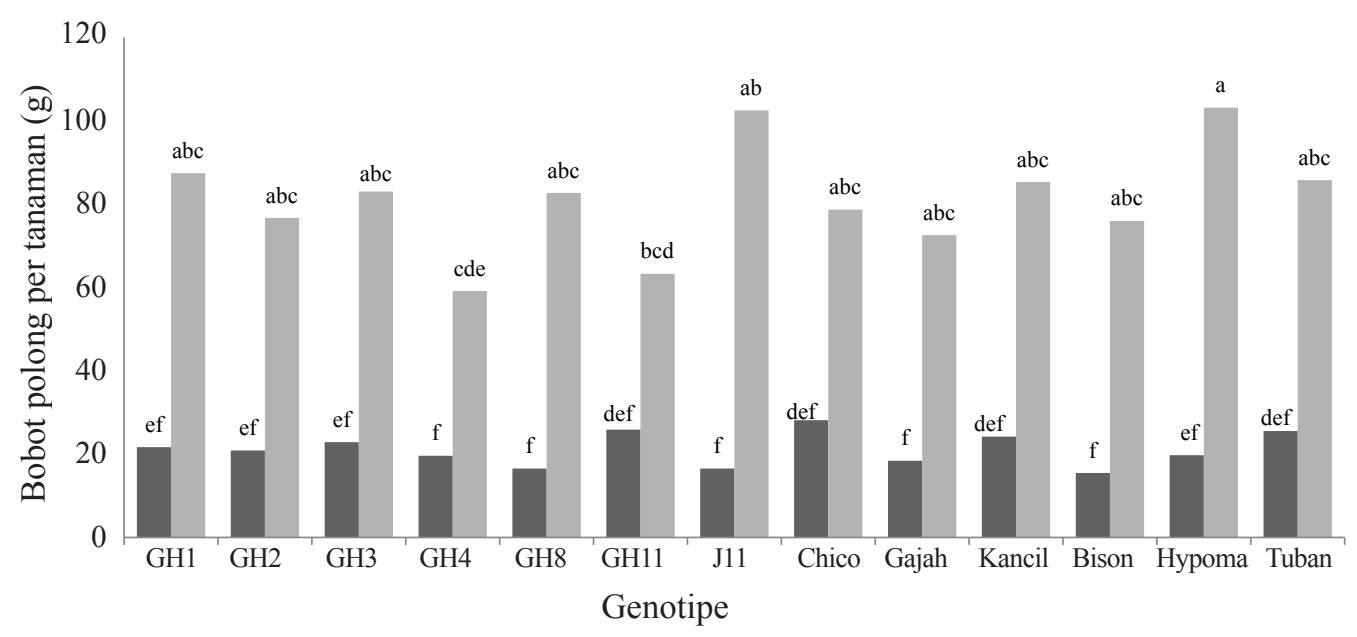

Gambar 4 Bobot polong per tanaman pada genotipe kacang tanah yang diinokulasi dan tanpa inokulasi patogen bercak daun Cercospora dan karat Puccinia. $\mathbf{0}$, dengan diinokulasi; , tanpa inokulasi. Huruf yang sama pada grafik menunjukkan tidak beda nyata BNT pada $\alpha 5 \%$.

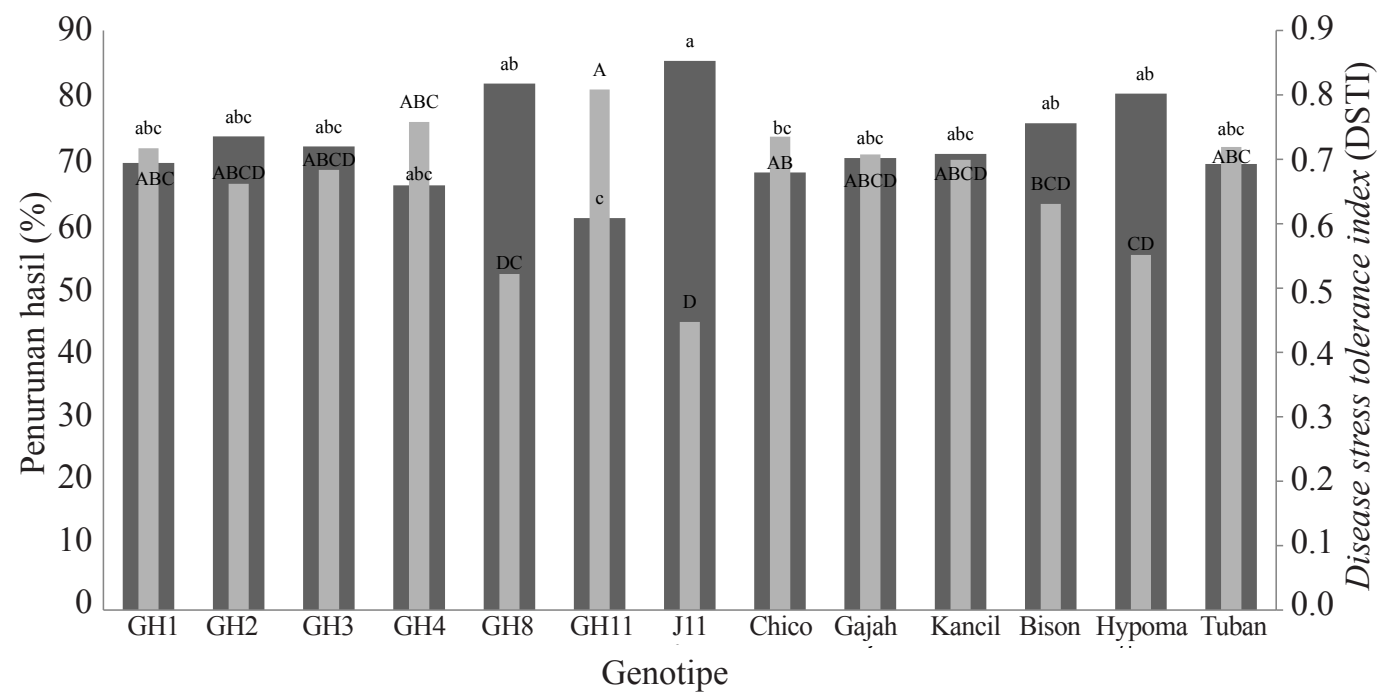

Gambar 5 Penurunan hasil polong per tanaman dan indeks toleransi terhadap penyakit (Disease stress tolerance index-DSTI) bercak daun Cercospora dan karat Puccinia pada genotipe kacang tanah. $\mathbf{0}$, penurunan hasil (\%); 1 , DSTI. Huruf yang sama pada grafik menunjukkan tidak beda nyata BNT pada $\alpha 5 \%$.

diameter bercak, masa inkubasi dan periode laten, intensitas penyakit, dan indeks sporulasi. Genotipe kacang tanah yang tahan penyakit bercak daun mempunyai masa inkubasi dan periode laten yang panjang, jumlah bercak sedikit, diameter bercak kecil, dan indeks sporulasi rendah (Ricker et al. 1985; Anderson et al. 1990; Dwivedi et al. 2002; Pensuk et al. 2003; Cantonwine et al. 2008).

Ketahanan genotipe kacang tanah terhadap penyakit karat juga rendah. Hanya satu genotipe, yaitu GH1 yang tergolong rentan, sementara genotipe lainnya sangat rentan. Genotipe kacang tanah yang tahan penyakit karat mempunyai masa inkubasi dan periode laten panjang, jumlah pustul sedikit, indeks sporulasi rendah, dan frekuensi infeksinya rendah (Subrahmanyam et al. 1985; Dwivedi et al. 2002; Fávero et al. 2009). Masa inkubasi penyakit karat dan periode laten semua genotipe uji relatif lebih panjang dibandingkan dengan penyakit bercak, namun perkembangan penyakit yang digambarkan oleh laju intensitas penyakitnya sangat cepat 
karena pengaruh lingkungan yang kondusif terhadap perkembangan patogen kelembaban tinggi (80-85\%) dengan suhu $25-28{ }^{\circ} \mathrm{C}$ sehingga intensitas penyakit karat telah mencapai lebih dari $70 \%$ pada 5 MSI.

Komponen seleksi lainnya yang juga penting untuk penilaian ketahanan terhadap penyakit daun, termasuk bercak daun dan karat ialah jumlah daun sehat (berwarna hijau) yang masih tersisa pada akhir pertumbuhan tanaman (Yudiwanti et al. 1998; Dwivedi et al. 2002). Infeksi bercak daun dan karat menyebabkan permukaan daun tertutupi oleh bercak hitam kecokelatan dan pustul menyebabkan bagian berwarna hijau yang berperan untuk fotosintesis berkurang dan menyebabkan daun gugur sebelum waktunya (defoliasi). Persentase defoliasi pada semua genotipe kacang tanah yang diuji relatif tinggi $(>50 \%)$, berkorelasi positif dengan intensitas serangan penyakit $(\mathrm{r}=0.36)$ dan berkorelasi negatif dengan dengan hasil kacang tanah $(r=-0.47)$. Hal ini sejalan dengan penelitian Hassan dan Beute (1977) dan Hossain et al. (2007) yang melaporkan persentase defoliasi rendah pada genotipe kacang tahan penyakit.

Penyakit bercak daun dan karat berpengaruh terhadap hasil dan komponen hasil diantaranya jumlah polong isi, jumlah polong hampa, jumlah polong chipo, dan bobot polong. Berkurangnya hasil dan komponen hasil kacang tanah disebabkan karena penyakit daun mengurangi jumlah daun produktif untuk berfotosintesis. Akibatnya suplai fotosintat untuk pembentukan polong terbatas dan menyebabkan hasil polong rendah. Selain itu, terbatasnya fotosintat yang dihasilkan juga mendorong terbentuknya banyak polong hampa dan banyak polong chipo berukuran kecil yang tidak memiliki biji. Kondisi ini sejalan dengan adanya korelasi negatif antara tingkat defoliasi dengan hasil kacang tanah yang terserang penyakit daun. Kehilangan hasil akibat penyakit bercak daun dan karat pada penelitian ini ialah $61-85 \%$ lebih tinggi daripada yang dilaporkan Subrahmanyam et al. (1985) bahwa kehilangan hasil oleh penyakit daun di daerah endemik di subtropik berkisar $50-80 \%$.
Toleransi suatu genotipe terhadap cekaman biotik akibat penyakit dapat diketahui melalui nilai indeks toleransinya. Richard (1996) melaporkan seleksi terhadap hasil yang dilakukan pada kondisi tercekam akan menghasilkan genotipe kacang tanah yang mempunyai nilai heritabilitas pada komponen hasil yang juga tinggi. Genotipe dengan nilai toleransi (DSTI) tinggi menunjukkan toleransi terhadap penyakit yang baik, potensi hasil yang tinggi, dan penurunan hasil yang rendah. Genotipe GH 11 mempunyai nilai DSTI paling tinggi, demikian juga GH 4. Kedua genotipe tersebut dapat dipertimbangkan untuk menjadi tetua persilangan untuk membentuk kacang tanah varietas tahan. Genotipe kacang tanah dengan nilai DSTI tinggi yang merupakan varietas yang sudah dilepas (Chico, Gajah, Tuban) dapat dipertahankan untuk tetap berproduksi tinggi pada kondisi tercekam penyakit daun dengan aplikasi fungisida untuk mengendalikan penyakit daun.

\section{UCAPAN TERIMA KASIH}

Penulis mengucapkan terima kasih kepada Novita Nugrahaeni (Kelompok Peneliti Pemuliaan dan Plasma Nutfah, Balitkabi), atas materi kacang tanah yang digunakan dalam penelitian ini

\section{DAFTAR PUSTAKA}

Anderson WF, Beute MK, Wynne JC, and Wongkae S. 1990. Statistical procedures for assessment of resistance in multiple foliar disease complex of peanut. Phytopathology. 80(12):1451-1459. DOI: http://dx.doi.org/10.1094/Phyto-80-1451.

Cantonwine EG, Culbreath AK, Stevenson KL, Kemerait RC, Brenneman TB, Smith NB, Mullinix BG. 2006. Integrated disease management of leaf spot and ppotted wilt of peanut. PlantDisease. 90(4):493-500. DOI: http://dx.doi.org/10.1094/PD-90-0493. Cantonwine EG, Culbreath AK, Holbrook CC, Gobert DW. 2008. Disease progress of early leaf spot and components of 
resistance to Cercospora arachidicola and Cercosporidium peronatum in RunnerType. Peanut Science. 1-10.

Dwivedi SL, Pande S, Rao JN, Nigam SN. 2002. Components of resistance to late leaf spot and rust among interspecific derivatives and their significance in a foliar disease resistance breeding in groundnut ( Arachis hypogaea L .). Euphytica. 125(1): 81-88. DOI: http:// dx.doi.org/10.1023/A:1015707301659.

Fávero AP, Moraes SA, De-Augusto A, Garcia F, Francisco J, Valls M, Vello NA. 2009. Characterization of rust, early and late spot resistance in wild and cultivated peanut germplasm. Sci Agric. 66(1):10-117. DOI: http://dx.doi.org/10.1590/S010390162009000100015.

Fernandez, G. 1992. Effective selection criteria for assessing plant stress tolerance. Di dalam: Proceedings of the International Symposium on Adaptation of Vegetables and Other Food Crops in Temperature and Water Stress; 1992 August 13-16; Tainan (TW): AVRDC Publication. hlm 257-270. http://scholar.google.com/scholar?hl=en\& $\mathrm{btnG}=$ Search\&q=intitle:Effective + selecti on + criteria + for + assesing + plant + stress + to lerance\# [diakses 16 Juni 2015].

Hassan HN, Beute MK. 1977. Evaluation of resistance to cercospora leafspot in peanut germplasm potenttially useful in breeding program. Peanut Science. 4(2):78-83. DOI: http://dx.doi.org/10.3146/i00953679-4-2-9.

Hossain MD, Rahman MZ, Khatun A, Rahman. 2007. Screening of groundnut genotypes for leaf spots and rust resistance. Int J Sustain Crop Prod. 2:7-10.

Pasupuleti J, Ramaiah V, Rathore A, Rupakula A, Reddy RK, Waliyar F, Nigam SN. 2013. Genetic analysis of resistance to late leaf spot in interspecific groundnuts.
Euphytica. 193(1):13-25. DOI: http://doi. org/10.1007/s10681-013-0881-7.

Pensuk V, Patanothai A, Jogloy S, Wongkaew S. 2003. Reaction of peanut cultivars to late leafspot and rust. Songklanakarin J Sci Technol. 25(3):289-295.

Power IL, Culbreath AK, Tillman BL. 2013. Characterization of resistance of peanut to Puccinia arachidis. Online Plant Health Progress. DOI: http://doi.org/10.1094/ PHP-2013-1125-02-RS.

Richard RA. 1996. Defining selection criteria to improve yield under drought. Plant Growth Regul. 20:157-166. DOI: http:// dx.doi.org/10.1007/BF00024012.

Ricker MD, Beute MK, Campbell CL. 1985. Components of resistance in peanut to Cercospora arachidicolla. Plant Disease. 69(12):1059-1064. DOI: http://dx.doi. org/10.1094/PD-69-1059.

Subrahmanyam P, McDonald D, Waliayar F, Reddy LJ, Nigam SN, Gibbons RW, Ramanatha RV, Singh AK, Pande S, Reddy M, Suba RPV. 1995. Screening methods and sources of resistance to rust and late leaf spot of groundnut. Information Bulletin. 47:21.

Subrahmanyam P, Reddy LJ, Gibbons RW, McDonald D. 1985. Peanut rust: a major threat to peanut production in the semiarid tropics. PlantDisease.69(9):813-819.DOI: http://dx.doi.org/10.1094/PD-69-813.

Sunkad G, Kulkarni S. 2006. Studies on structural and biochemical mechanism of resistance in groundnut to Puccinia arachidis. Indian Phytopathol. 59(3):323328.

Yudiwanti S. Sastrosumarj S, Hadi, Karama A, Surkati, Mattjik A. 1998. Korelasi genotipik antara hasil dengan tingkat ketahanan terhadap penyakit bercak daun hitam pada kacang tanah. Bull Agro. 26(1):16-21. 